\title{
Meer openbaarheid, meer vertrouwen?
}

\author{
Stephan Grimmelikhuijsen*
}

\section{Een democratisch ideaal}

Transparantie als democratisch ideaal is onomstreden. Daarnaast wordt door velen en ook door de Raad voor het openbaar bestuur (Rob) openbaarheid van overheidsinformatie gezien als dé remedie voor een belangrijke kwaal: het wegzakkende vertrouwen van burgers in politiek en overheid. Daarom is het verbeteren van de openbaarheid voor burgers een van de centrale aanbevelingen uit het rapport Gij zult openbaar maken. Het rapport pleit onder meer voor een nieuwe Wet op de overheidscommunicatie in plaats van de huidige Wet openbaarheid van bestuur (Wob). Dit markeert dat openbaarheid een 'recht is van burgers, niet een gunst van de overheid' (Raad voor het openbaar bestuur, 2012, 70). 'Toegang tot overheidscommunicatie stelt burgers in staat om hun diverse rollen - als kiezer, coproducent van beleid, onderdaan of klant - optimaal te vervullen' (p. 71). Daarnaast zou de wet concrete instructienormen voor overheden moeten bevatten: informatie moet begrijpelijk, tijdig en juist zijn.

Niemand zal ontkennen dat er een stevige waarborg voor transparantie nodig is in een democratie. In een recent proefschrift waarin Erna Scholtes (2012) duizenden Kamerstukken en debatten heeft geanalyseerd, blijkt dan ook dat de term 'transparantie' sterk in populariteit is toegenomen de afgelopen jaren. Echter, transparantie lijkt soms gezien te worden als absolute waarde, een waarde die te allen tijde verheven is boven andere publieke waarden.

De vraag of een transparantere overheid zal leiden tot meer vertrouwen is daarentegen complex en hangt in belangrijke mate af van twee cruciale vragen die in het Rob-rapport en in wetenschappelijk onderzoek in het algemeen onderbelicht blijven: openbaarheid voor wie en openbaarheid van wat? Ten eerste zijn er grote verschillen in het type informatie dat overheidsorganisaties openbaar kunnen maken: van informatie die democratische controle dient (denk bijvoorbeeld aan gemeenteraadsstukken) tot informatie om mensen te informeren over nieuw beleid. Ten tweede zullen verschillende typen burgers op uiteenlopende wijzen omgaan met overheidsinformatie en dit zal dus verschillende uitwerkingen hebben op het vertrouwen.

In deze beschouwing zal worden ingegaan op de link tussen overheid en burger en hoe transparantie hier effect op heeft. Daarbij ga ik in het bijzonder in op 'vertrouwen in de overheid' omdat, zoals ook in het rapport wordt aangegeven, het vergroten van vertrouwen in de overheid nationaal en internationaal wordt gezien als een belangrijk doel van openbaarheidsinitiatieven (Worthy, 2010; Raad voor het openbaar bestuur, 2012)

* Stephan Grimmelikhuijsen is onderzoeker en docent aan de Universiteit Utrecht, e-mail: s.g.grimmelikhuijsen@uu.nl. 
Stephan Grimmelikhuijsen

\section{Transparantie van wat?}

Allereerst hangt het effect van openbaarheid af van het type informatie. Zo kunnen er verschillende vormen van transparantie worden onderscheiden. Ik zal er hier drie uitlichten: informatie over besluitvorming, informatie over beleid en informatie over geboekte resultaten. Uit mijn promotieonderzoek blijkt dat elk van deze vormen andere effecten heeft op het vertrouwen van burgers. ${ }^{1}$ Deze zal ik hieronder kort bespreken.

Bij besluitvormingstransparantie is specifiek gekeken naar wat het effect is van het lezen van complete en incomplete informatie over (lokale) besluitvorming op het vertrouwen van mensen. Eén groep respondenten fungeerde als controlegroep en kreeg geen informatie voorgelegd. Een tweede groep kreeg slechts een korte samenvatting van het besluitvormingsproces te zien, terwijl een derde groep complete informatie ontving. De complete informatie is een bijna letterlijke transcriptie van een besluitvormingsdiscussie in de gemeenteraad. Uit de resultaten blijkt dat mensen die complete informatie voorgelegd kregen minder vertrouwen in de competentie van de raad, maar meer vertrouwen in de eerlijkheid van de raad. Kortom, besluitvormingstransparantie heeft een heterogeen effect op het vertrouwen van burgers.

Ten tweede is er transparantie van beleid, waarbij de informatie zich richtte op beleidsmaatregelen. Hier kregen groepen respondenten verschillende soorten 'gekleurde' informatie te zien, variërend van tweezijdige tot zeer positieve informatie. Hieruit bleek dat er slechts geringe effecten van beleidstransparantie optraden. Wanneer gebalanceerde informatie over beleidsmaatregelen wordt gegeven - met andere woorden: wanneer expliciet wordt benoemd dat niet alles goed gaat -, wordt de competentie van de overheidsorganisatie lager beoordeeld dan wanneer licht positieve beleidsinformatie wordt gegeven. Aan de andere kant heeft het geven van uitsluitend zeer positief geformuleerde informatie een minder gunstig effect. Licht optimisme over het eigen beleid wordt gewaardeerd door respondenten.

De derde vorm van transparantie is die van beleidsuitkomsten. Hierbij werd gevarieerd op de tijdigheid en begrijpelijkheid van die informatie. De uitkomsten wijzen erop dat transparantie van beleidsuitkomsten wordt gezien als een 'hygiënefactor'. Wanneer niet wordt voldaan aan het ideaal van transparantie - dus wanneer ontijdige en moeilijk begrijpbare informatie wordt gepresenteerd -, zal dit leiden tot een daling in het vertrouwen. Aan de andere kant, wanneer de bruikbaarheid wel hoog is, zal dit niet leiden tot meer vertrouwen in vergelijking met de mensen die geen informatie kregen over de beleidsuitkomsten. Kortom, een overheidsorganisatie kan het wel verkeerd doen, maar nauwelijks goed.

\section{Transparantie voor wie?}

De relatie tussen transparantie en het vertrouwen van burgers ligt echter (nog) complexer. Naast de informatie die verzonden wordt, zijn degenen die deze informatie ontvangen net zo belangrijk. Zo zijn voor functionele transparantie 'recep- 
toren' nodig, oftewel burgers die overheidsinformatie lezen (Heald, 2006). Maar eigenlijk weten we heel weinig over deze ontvangers: 'de burger' bestaat niet. Sociaalpsychologische theorieën helpen om de reactie van mensen op overheidsinformatie te begrijpen. Zo geeft sociaal psycholoog Kees van den Bos (2011) in een essay voor het ministerie van Binnenlandse Zaken en Koninkrijksrelaties aan dat mensen van nature een bepaalde hoeveelheid vertrouwen in de overheid hebben. Wanneer zij geen idee hebben of ze de overheid kunnen vertrouwen, zoeken zij informatie om hun vertrouwen op te baseren. Als het gaat om vertrouwen in de overheid is kennis dus een belangrijk onderdeel (zie ook Lewicki, McAllister \& Bies, 1998).

In een recente studie (Grimmelikhuijsen \& Meijer, 2013) is er gekeken naar hoe deze twee bepalende factoren - reeds bestaande houding en hoeveelheid kennis - de reactie van burgers op transparantie kunnen beïnvloeden. Je zou op basis van deze twee factoren grofweg vier typen burgers kunnen onderscheiden:

1. De 'wantrouwende burger', die weinig kennis heeft én weinig vertrouwen.

2. De 'naïeve burger', die weinig kennis heeft maar veel vertrouwen.

3. De 'overheidminnende burger', die veel kennis heeft én veel vertrouwen.

4. De 'kritische burger', die veel kennis heeft, maar weinig vertrouwen.

Wanneer elk van deze 'type' mensen informatie leest van de overheid, lokt dit andere reacties uit. De resultaten waarover ik hier rapporteer gaan overigens specifiek over het openbaar maken van (positieve) beleidsresultaten. Wat gebeurt er wanneer mensen hierover lezen?

Kritische en overheidminnende burgers hebben veel kennis en veranderen daardoor niet snel van houding ten opzichte van de overheid. Zij krijgen weinig tot geen nieuwe informatie, daar zij deze uit andere bronnen halen (Grimmelikhuijsen \& Meijer, 2013).

Dit is anders wanneer burgers nog weinig kennis hebben voorafgaand aan het lezen van informatie. Welk effect de informatie dan precies heeft, hangt af van iemands basishouding ten opzichte van de overheid. Bij burgers die al veel vertrouwen hadden (de 'naïeve burger'), zien we een plafondeffect optreden. Het vertrouwen is al zo hoog dat hier weinig ruimte voor stijging is. Sterker nog, zij raken in zekere mate zelfs teleurgesteld: hun hoge mate van basisvertrouwen wordt door beleidsresultaten niet waargemaakt, zelfs niet als het gaat om positieve beleidsresultaten. Het vertrouwen in de competentie van de overheid neemt af. De wantrouwende burgers zijn echter positief verrast en krijgen meer vertrouwen in de welwillendheid van de overheid om in het belang van burgers te handelen (Grimmelikhuijsen \& Meijer, 2013).

\section{Geen wondermiddel}

Welke conclusie kunnen we trekken wanneer we deze nuances overzien? De gedachte dat transparantie het vertrouwen in overheidsorganisaties als vanzelf zou vergroten, is gangbaar en ook terug te vinden in het Rob-rapport. De bevindingen laten echter zien dat de belofte van transparantie gerelativeerd moet wor- 
Stephan Grimmelikhuijsen

den, en dat het uitmaakt welke informatie naar buiten komt en wie deze informatie leest.

Voor beleidsmakers betekent deze nuancering op het Rob-rapport niet dat we de poorten van de overheid dan maar moeten sluiten. Los nog van andere mogelijke doelen - verantwoording, bestrijden van corruptie of misstanden - gaat het niet altijd om de effecten van openbaarheid. Het is niet altijd slecht wanneer mensen minder vertrouwen in de overheid of politici hebben: vertrouwen moet verdiend worden. Een zekere kritische en wantrouwende houding is voor een democratie zelfs van vitaal belang (Hardin, 2002).

Daarnaast zijn er aanwijzingen uit ander onderzoek dat op lange termijn transparantie wel degelijk zorgt voor algemeen vertrouwen in de overheid. Zo laat Amerikaans onderzoek zien dat meer openbaarheid in eerste instantie meer corruptieveroordelingen aan het licht brengt. Echter, op lange termijn neemt het aantal corruptieveroordelingen juist af (Warren \& Cordis, 2011). Landenvergelijkend onderzoek van Van der Meer (2009) laat een verband zien tussen lage corruptieniveaus en hoge niveau van vertrouwen.

Op korte termijn is het echter voor individuele organisaties niet erg aantrekkelijk om opener te worden. Transparantie kan ervoor zorgen dat er negatieve informatie naar buiten komt, wat het vertrouwen kan laten dalen. Echter, op lange termijn zou openbaarheid wellicht een zuiverend effect kunnen hebben op overheidsorganisaties. Aan de zijde van burgers zou een grotere openheid op lange termijn kunnen bijdragen aan 'politieke volwassenheid': burgers die zich ervan bewust zijn dat politieke en beleidsprocessen niet altijd optimaal verlopen, zullen in de toekomst wellicht minder snel teleurgesteld raken in de overheid.

Ondanks eventuele negatieve bijwerkingen moet transparantie als ideaal in een democratie stevig zijn. Wonderen moeten we niet verwachten, maar we kunnen wel kijken voor welke soorten informatie en voor welke doelgroepen burgers openbaarheid extra van waarde kan zijn.

\section{Noot}

1 Resultaten zijn eerder gepubliceerd in Grimmelikhuijsen (2012).

\section{Literatuur}

Bos, K. van den (2011). Vertrouwen in de overheid: wanneer hebben burgers het, wanneer hebben ze het niet, en wanneer weten ze niet of de overheid te vertrouwen is? Den Haag: Ministerie van Binnenlandse Zaken en Koninkrijksrelaties.

Grimmelikhuijsen, S.G. (2012). Transparency and trust. An experimental study of online disclosure and trust in government ( $\mathrm{PhD}$ thesis, Utrecht University).

Grimmelikhuijsen, S.G., \& Meijer, A.J. (2013). The Effects of Transparency on the Perceived Trustworthiness of a Government Organization: Evidence from an Online Experiment. Journal of Public Administration Research and Theory, early access.

Hardin, R. (2002). Trust and trustworthiness. New York: Russell Sage Foundation. 
Heald, D. (2006). Varieties of transparency. In: C. Hood \& D. Heald (Eds.), Transparency: The key to better governance? Oxford: Oxford University Press, 25-43.

Lewicki, R.J., McAllister, D.J., \& Bies, R.J. (1998). Trust and distrust: New relationships and realities. Academy of Management Review, 23 (3): 438-458.

Meer, T. van der (2009). Politiek vertrouwen internationaal verklaard. In: P. Dekker, T. van der Meer, P. Schyns \& E. Steenvoorden (red.), Crisis in aantocht? Den Haag: Sociaal en Cultureel Planbureau, 94-112.

Raad voor het openbaar bestuur. (2012). Gij zult openbaar maken. Naar een volwassen omgang met overheidsinformatie. Den Haag: Rob.

Scholtes, E. (2012). Transparantie. Icoon van een dolende overheid. Den Haag: Boom Lemma uitgevers.

Warren, P.L., \& Cordis, A.S. (2011). Sunshine as Disinfectant: The effect of Freedom of Information Act laws on public corruption. Paper presented at the First Global Conference on Transparency Research, Newark, NJ.

Worthy, B. (2010). More open but not more trusted? The effect of the freedom of information act 2000 on the United Kingdom central government. Governance: An International Journal of Policy, Administration, and Institutions, 23 (4): 561-582. 